PHILOLOGY

\title{
COMMON AND DISTINCTIVE FUNCTIONS OF THE PROTAGONIST HERO IN FOLKTALE AND FANTASY (BASED ON PROTAGONIST HEROES IN THE WORKS OF J.R.R. TOLKIEN AND NATO DAVITASHVILI)
}

\author{
Tamar Katamadze \\ PhD Candidate in Literature, Batumi State University \\ Batumi, Georgia
}

DOI: https://doi.org/10.31435/rsglobal_wos/31102019/6744

\section{ARTICLE INFO}

Received: 13 August 2019

Accepted: 17 October 2019

Published: 31 October 2019

\section{KEYWORDS}

Protagonist,

Hero,

Function,

Fantasy,

Genre,

Magic,

Weapon,

Folktale,

J.R.R. Tolkien,

Demigod,

Abyss,

Sword,

Helper,

Mentor,

Nato Davitashvili.

\begin{abstract}
The article deals with the main functions of the protagonist hero in the fantasy literature. Fantasy literature is similar to folktale not only due to the fact that it contains magic and supernatural elements. By comparing the functions of fantasy protagonist hero with the functions of folktale protagonist hero, described by V. Propp in "Morphology of the Folktale", it can be noticed that they have many similarities. The article discusses two main fantasy heroes: Frodo Baggins (J.R.R. Tolkien's "The Lord of the Rings") and Lile Iroeli (Nato Davitashvili's "The story of Lile Iroeli"). By comparing them, can be concluded that the basic traits of functions of protagonist hero in both, English and Georgian literary works come out from folktale roots. Thus, the protagonist leaves home, he is given a task, he is tested, attacked, he acquires a magical weapon, he defeats and punishes the villain, the hero is married or ascends the throne.

In the model of functions in question, we can insert the heroes of both types and still the main idea of the stories will be presented. However, both protagonists being in the fantasy story have acquired some other functions we do not meet in the folktale. The task given to both heroes is to save the world from an evil villain, who wants to rule the whole world. Consequently, fantasy protagonist fights against the global enemy. Both heroes are not as courageous as the heroes of the folktale are. They have helpers, closest friends who support them in crucial moments. They have wise mentors, who give them tasks and the fellowship of other heroes, including invented creatures or speaking animals. Each hero of the fantasy genre is given his own name, as opposed to the folktale where the heroes have generalized names: the old man, stepmother, princess, king etc.

In conclusion, the article presents functions of fantasy protagonist character, who takes the roots from folktale, but in the development of new genre it has acquired other distinctive elements, which distinguish him from the folktale protagonist hero.
\end{abstract}

Citation: Tamar Katamadze. (2019) Common and Distinctive Functions of the Protagonist Hero in Folktale and Fantasy. (Based on Protagonist Heroes in the Works of J.R.R. Tolkien and Nato Davitashvili). International Academy Journal Web of Scholar. 10(40), doi: 10.31435/rsglobal_wos/31102019/6744

Copyright: (C) 2019 Tamar Katamadze. This is an open-access article distributed under the terms of the Creative Commons Attribution License (CC BY). The use, distribution or reproduction in other forums is permitted, provided the original author(s) or licensor are credited and that the original publication in this journal is cited, in accordance with accepted academic practice. No use, distribution or reproduction is permitted which does not comply with these terms.

Fantasy literature is similar to folktale not only because it contains magic and supernatural elements. There are many other similarities between them. The article discusses the main characteristics of fantasy protagonist hero from English and Georgian literature and compares their functions with the main functions of a folktale hero, taken from V. Propp's "Morphology of Folktale". 
The study is conducted with the comparative methodology and descriptive approach. The research attempts to discover what characteristics of fantasy hero are taken from a folktale hero and what kind of qualities and functions has it acquired, which we can't meet in the folktale.

Protagonist hero is the main character of a Fantasy story whose function is to solve the main conflict. In Fantasy story as well as in folktale he is often presented as an inexperienced young man who is seen as a strong, wise and brave man at the end of the story. Fantasy protagonist hero is mainly a round and dynamic type of character. With personal qualities and functions, he reminds us of a folktale hero. If we compare two fantasy protagonists, Frodo Baggins (J.R.R.Tolkien's "The Lord of the Rings") and Lile Iroeli (Nato Davitashvili's "The Chronicles of Iroelis"), we can conclude that they take their roots from folktale protagonists.

Here are the functions of folktale protagonist that we can meet in these two fantasy stories:

One of the members of the family absents himself from home. (Propp, 2009:26). This function has subtitles: 1) The person absenting himself can be a member of the older generation. In "The Lord of the Rings" Bilbo Baggins leaves home, and he leaves his whole heritage and his most precious thing, the ring, to Frodo, his heir and relative. 2) An intensified form of absentationis represented by the death of parents. We can see the same function as the second subheading in the story written by NatoDavitashvili. Lile's both parents are dead. The reason of Father's death is not stated. His mother died while giving birth to him. Both heroes live without parents. Therefore, the functions of Frodo and Lile coincide with those of folktale hero.

The hero leaves home (Propp, 2009:39). Propp explains that this kind of departure is different from leaving house temporarily. According to him, there is a difference between the departure of a seeker-hero and a departure of a victim-hero, who starts his journey, and various adventures await him. Propp says that in some stories we do not have a route and "the entire action takes place in one location". In fantasy story, the route passed by the protagonist is very long and full of differences and with such complicated territories that the reader needs a map to observe the location of the protagonist.

Frodo leaves Bag End soon after he gets advice from Gandalf. He has the Ring the Dark Lord Sauron is looking for, so Frodo must leave his village, not to endanger Hobbiton. Here starts his long way to Mordor. Lile is brought up among the Devis (A Giant, one or several-headed ogre from Georgian mythology). Buknai Baaduri the Monk is looking forward to his growth. He wants to see Lile as an adult man who will fulfill his mission and break the Bowl of Grief. He leaves his house by accident, falls down the cliff and lands up in the world of "Katsmatsuna" (a kind of dwarves), then in the country of the Dalis (Land inhabited only by women), then in the Abiss and he fulfills his mission everywhere and helps all these nations to combine their forces against their common enemy. The universe calls Lile Iroeli everywhere, where the order has to be restored. If we observe the beginning of the route of both these heroes, we discover that both of them were obliged to leave their homes, which makes them a dynamic type of person.

The hero acquires the use of a magical agent (Prop, 2009:43). Propp speaks about different magical agents, including a sword. Frodo has a sword, made by elves, having a special feature: when orcs are approaching, it turns blue, indicating its owner about the danger. Lile has a special sword as well. His weapon was made by Pirkushi (the demigod from Georgian mythology) with Khalibian steel on the Flaming Lands. Only this kind of sword can break the Bowl of Grief. The sword gives out light in the darkness. Besides, Lile has a magic necklace with the ornament of the sun, the sign of Iroeli, as a descendant of this surname, which also shines in the darkness.

A difficult task is proposed to the hero. (Propp, 2009:87). Prop provides different examples of tasks given to the hero: ordeal by food and drink (he must eat a certain number of bread or drink great amount of beer). Ordeal by fire (he must bathe in a red-hot iron bathhouse). Riddle guessing and similar ordeals (to pose an ambiguous riddle, to interpret a dream, to find out marks on something); ordeal of choice (to select sought-after persons among twelve identical girls/boys); hide and seek (hide oneself so that discovery is impossible); test of strength, adroitness, fortitude, test of endurance, and many other tasks. This function is followed by another one: The Task is Resolved. Folktale hero generally manages to resolve even the most complicated task rather easily, without any efforts, with the help of a magical agent. The problem of folktale hero is private (family conflict, proving love), but the way of fantasy protagonist is more complicated, and the task is almost impossible. He has to save the world from the common enemy that is going to rule the whole universe.

The hero is transferred, delivered or led to the whereabouts of an object of search (Propp, 2009:50). The object of search and the destination of the hero is in another, "secondary world" (term coined by J.R.R. Tolkien in his seminar essay "On Fairy Tales" for a particular kind of otherworld in 1939 
(Clute,1997 :847). For an ordinary man it is impossible to pass this way. The folktale hero manages it through the help of a magic agent. However, for fantasy protagonist magic things are only additional elements for overcoming one or several obstacles. He usually passes the way himself, with his own efforts. Frodo has a difficult way of going to Mordor. He has to manage to take and destroy the ring there without Sauron noticing it. He has two attendants Sam Gamgee - his devoted friend and Gollum-Smeagol, false supporter hero, whom they took for directing their route. The real purpose of Gollum is to separate Frodo and Sam and take away the ring from its bearer. Lile Iroeli goes down to Abyss with Rufia (an imp who was exorcized and dwelling in the body of a crow). Lile does not use magic things to reach the destination. First they go through the underground labyrinths lead by Katsmatsuna Abo (a kind of dwarf), at the end of the labyrinth through the connecting gate they go down to Abyss. Therefore, this function of the protagonist in the fantasy literature is expressed in more details, here are physically and logically explained the difficulty of the protagonist route and the reader can clearly see the difficult task the protagonist has to tackle. Besides, the route a folktale hero has to pass is uncertain and it is somehow vaguely expressed in the phrases: "once upon a time", "beyond the mountains", "he came to a small village", "he crossed the river" etc. In a fantasy story every mountain, river and every location is given a name. e.g. rivers - Erui, Poros, Serni, Sirith, Ringlo, Gilrain etc. Mountains - Ephel Duath (mountains of Shadow), Udun, Barad-Dur, Ered Lithui, Ered Nimrais, Mount Doom etc.

The hero and the villain join in direct combat. The villain is defeated. (Propp, 2009:51). In folktale the combat of the protagonist and antagonist is presented in a simple way. Here the antagonist is mainly a physical hero, who can be defeated with the help of physical strength or smart mind. V.Propp gives four ways of their combat: 1) They fight in an open field (physical fight), 2) They engage in a competition (the hero wins with the smartness), 3) They play cards (entrust themselves to luck), 4) presents a special form: e.g., a she-dragon proposes the following to the hero "Let Prince Ivan get on the scales with me; who will outweigh the other?" (Use of laws of physics).

Fantasy antagonist is not a fully physical hero. His existence is strengthened by magic, which cannot be overcome by other villain. He can only be defeated by one action: Someone must destroy the source of its power. Therefore, it must be done not by someone the villain knows and observes, but by someone else, granted with a special gift. Why did Tolkien choose Frodo Baggins to destroy the ring? Why did not he choose Gandalf, who is wiser, or Aragorn and Legolas, who are famous with their bravery and experience? Tolkien does not need the hero who will physically fight with Sauron and defeat him, but he needs the hero who will destroy the ring and in this way will wipe out his power. To destroy the ring, someone must take it to the Mount Doom and throw it into the fire where it was originally made. Hobbits are creatures who like comfort. They live in their holes; enjoy eating and smoking pipes. They do not have fighting skills at all, but they can hide from enemies skillfully. These small-bodied creatures can disappear within seconds in the nearby bushes and holes when something threatens them. Tolkien needs exactly this kind of a hero, who can carry the ring to Mordor so as to stay unnoticeable to Sauron's Eye. Besides, hobbits are full of endurance, and among them Frodo is especially known as having a purposeful and steady character. Consequently, walking on the difficult road to Mordor and carrying a magic ring is only possible by a hobbit like Frodo.

Lile Iroeli, on the other hand, was brought up as a warrior. He was granted by God the Creator with special abilities and his destiny was obvious to the chief demigod Buknai Baaduri the Monk even before his birth. Lile has to destroy the Bowl of Grief. Every tear of unhappy and suffered people that drop from their eyes, leak to this bowl as bitterness and collects in it. Once a year Samsala and his servants drink a handful of bitterness from the bowl and get their undefeatable power. The more people are suffered by these evil spirits, the more drops of tears fall into the Bowl of Grief and it is likely that soon Samsala will get his governance over the whole world. However, God the Creator and demigods are looking for the salvation. Lile's birth was predicted in the old scriptures and all the demigods and governors were looking forward to this special event. His blood was the mixture of three origins: of men, demigods and Kajis (a kind of evil creature, like an imp from Georgian mythology) that is why the stroke of sword he makes has a great power and this is the reason that such a great mission was put on Lile, rather than experienced demigods who were great warriors. It is very interesting that before going down to Abyss Buknai Baaduri the Monk warns Lile: "Don't forget, we are sending you down to Abyss only to destroy the Bowl of Grief. Avoid any kind of grappling with the Dark Lord. Even if he bows before you and asks you to slaughter him, first of all destroy the Bowl and then deal with him" (coszoos $\partial_{3}$ omo, 2010:356). From the examples of Frodo Baggins and Lile 
Iroeli it is obvious that a fantasy hero does not have enough strength to involve in the physical fight with evil antagonist. He has to destroy the agent that gives power to Dark Lord.

The hero is branded (Propp, 2009:52). In folktale, the branding of the main hero is not as important as in fantasy. If in the folktale a kind of a wound or any mark on his body has only a function of recognition or marking, in fantasy stories we see this process as a punishment for the protagonist's bravery to meet the Dark Lord. Frodo, standing at the edge of the Cracks of Doom, was still hesitating whether to destroy the ring or not and at last he was tempted by the ring and he put it on his finger and disappeared. That very moment Gollum jumped on his back and he swayed back and forth, fighting with the invisible foe. "Suddenly Sam saw Gollum's long hand draw upwards to his mouth; his white fangs gleamed, and then snapped as they bit. Frodo gave a cry, and there he was, fallen upon his knees at the chasm's edge" (Tolkien, 1986:240). Frodo lost his finger and it was a kind of sacrifice for his bravery. As for Lile, he went down to the Abyss to destroy the Bowl of Grief. Samsala had sent all his servants to the war and being alone, he was emptied from power, so he tried to tempt Lile, spoke to him and in the meanwhile was trying to gather his power again. Lile destroyed the Bowl and he felt all the pains of every drop of the bitterness. The pain was unbearable, Lile could not resist it anymore, and Rufia had no other choice but to put a small drop of the bitterness with its feather to Lile's lips and save his life. No man should have even touched any drop of bitterness; otherwise, it would destroy him. Lile bore his spiritual wound all his life and after many years this pain was so unbearable that he joined the land, where the drops of the bitterness had leaked and he became the element of Land (the last book of the Chronicles of Iroeli "Aya's Way"). Therefore, we see that the wounds of fantasy heroes are eternal and more painful and the reason is the fact that the Evil that protagonist fights against has a much greater dimension than in folktale.

One more thing that distinguishes a fantasy protagonist from folktale hero is that in fantasy the hero's inner emotional condition is shown more openly than in folktale. If, on the one hand, a folktale hero is brave, strong and undefeatable, on the other hand, we often see a fantasy hero tired, frightened and weak. He necessarily needs a helper who supports him in the most critical situation. He also needs a wise mentor who gives him the task and directives, and he also needs a group of helpers (fellowship) including invented creatures and speaking animals.

Some critics think that Tolkien presented a different image of hero through Frodo - Humble Heroism - and they discuss him as being a Christian hero. Someone having the least power must take the ring to Mordor. The ring has its tempting influence, so the humbler and less powerful the Ringbearer is, the less influence it will have on him (Dalfonzo, 2007:2). Frodo is a humble hobbit, with strong inner personality. As he is approaching the destination, the ring is getting heavier but Frodo does not surrender to this difficulty. He knows that he may die while fulfilling this task but he is ready for this sacrifice and his main goal is to save the world. This is the reason why the Critics Joseph Pearce and Bradley J. Birzer compare Frodo to Christ. Birzer writes, "Fulfilling the role of priest, he carries the Ring - the cross of Christ, the sins of the world - into the heart of hell (Mordor). Frodo does this out of profound love for his friends and for life itself" (Dalfonzo, 2007:2).

Fantasy authors openly speak about the weaknesses of the hero. In folktale, the main hero who manages to resist his enemy rather easily gains the final victory. In fantasy story, the victory is gained by coalition of fellowship where the decisive role depends on the persistence of the protagonist. It is hard to imagine what would happen if Frodo was not accompanied by Sam. He is his constant motivator. They still had two day's walk left to the Mount Doom when Frodo said, "I can't manage it, Sam. It is such a weight to carry, such a weight" (Tolkien, 1986:228). Sam suggested that he would carry the ring for him but after getting Frodo's refusal, he offered another alternative - to throw away the whole luggage and save energy. When the next day he saw that Frodo could not even stand on his feet, he promised that he would carry him to the Mount Doom on his back even if it would "break (his) back and heart", and he did it.

The victory of Frodo was not only Sam's contribution, but also of the members of the fellowship. They decided to attack against the army of Sauron in order to attract his great eye from the Mount Doom to the battle and not to see Frodo and Sam climbing towards the mountain. (Tolkien, 1986:160). Frodo tries to defeat the Dark Lord by destroying the magic agent, while the fellowship is fighting physically against the great army of orks.

A similar scene of the decisive battle we see in the story of Lile Iroeli. While Lile and Rufia are trying to go down to the Abyss, Buqnai Baaduri the Monk and other demigods are fighting against the army of kajis in the territories of Samshvilde and Dmani. The demigods attracted Samsala's attention to Samshvilde and made him send all his army there and stay alone in the Abyss. Here is 
given the important role of secondary hero in the decisive battle. Lile is accompanied with Rufia, former white kaji (imp) who dwelled in the body of a crow after exorcism. Apart from being the only guide, Rufia is always observing Lile's actions and tries to help him fulfill his task. When they approach Samsala's castle, Lile tries to make the burning clouds obsess him with his mind and soon he loses his power and faints. Rufia is sitting near him as a guard, patiently waiting until Lile comes round. Even when the guard-snakes approach them, Rufia misleads them to a different direction, away from Lile and so he saves the hero. When breaking the Bowl of Grief, he encourages Lile and tells him not to listen to Samsala's tempting words and break it at once. If Rufia were not with Lile, things might have developed differently. In both stories, the secondary heroes that accompany the protagonist take great contribution to fulfilling the final mission.

When we speak about the inner spiritual condition of the protagonist, it is also important to discuss them in the aspect of the hero returning home. In the "Morphology of the Folktale" V. Propp has mentioned the point of returning home (Propp, 2009:55), but here he speaks about general returning, when a hero goes to search something or somebody, finds it and returns to its starting position. In the fantasy story, childhood home has meaning that is more important. Usually, when Fantasy protagonist starts its journey, he has an interesting and exciting life ahead, great recognition, fame, award, but in difficult situations, he is always missing his home, starting point when he was free from the responsibility of saving the world. Lile disappeared after breaking the Bowl of Grief. Buqnai Baaduri the Monk and other demigods were looking for him everywhere. They thought that he was killed in the Abyss, or he was alive but could not escape from there and demigod Kopala was planning to go down and save him, but they got the news that Lile was in Roshkash, in his home village, with the family of the Devis who brought him up. He spends some time there, constantly thoughtful and dreary, trying to rehabilitate himself in the depth of nature and solitude. Thus, the author shows the inner pain of the hero that is beyond his fame. Sam and Frodo, being very close to their destination, speak about heroism and its painful nature. When Frodo explains how he hates the environment around, the way, every "step or stone, breath or bone, earth, air and water", Sam admits: "we shouldn't be here at all, if we'd known more about it before we started. However, I suppose it is often that way. The brave things in the old tales and songs... I used to think the wonderful folk of the stories went out and looked for, because they wanted them, because they were exciting and life was a bit dull, a kind of a sport, as you might say. However, it is not the way with the tales that really matter or the ones that stay in the mind. Folk seem to have been just landed in them, usually - their paths were laid that way, as you put it. But I expect they had lots of chances, like us, of turning back, only they didn't. And if they had, we shouldn't know, because they'd have been forgotten. We hear about those as just went on - and not all to a good end... I wonder what sort of a tale we've fallen into?"' (Tolkien 1986:362)

Such a dialogue cannot be met in a folktale. We may say that it is because folktale is short and it is impossible to present long dialogues of the heroes, however one thing is obvious: Fantasy hero is not always presented as brave and courageous, the author often shows their weak sides.

As we have seen, some functions of the fantasy hero and the folktales are identical. These two fantasy heroes have adopted the following functions of a folktale:

One of the members of the family absents himself from home; the hero leaves home; the hero acquires the use of a magical agent; a difficult task is proposed to the hero; the hero is transferred, delivered or led to the whereabouts of an object of search; the hero and the villain join in direct combat. The villain is defeated; the hero is branded; the hero returns home.

Besides these main characteristics of folktale, we see with two fantasy protagonists, Fordo Baggins and Lile Iroeli, there are other different functions that should be mentioned. The following aspects show the difference between the folktale and fantasy protagonists:

1) Fantasy heroes have personal names. Even the least important hero is presented with name. Protagonist is described through genealogy and we even know their ancestors by names.

2) Fantasy protagonist hero is not ideal. He is afraid of something, he is bored, or angry, disappointed etc. The author describes the weak sides of their personality that evoke sympathy in the reader and it is not a humiliation of the hero.

3) Fantasy protagonist is not fighting to solve his personal problems. He is fighting against evil, who is trying to gain power over the whole world or the region.

4) Fantasy protagonist does not involve in the common fighting by his desire. He is ordered to do so, or such is his destiny. 
5) Fantasy protagonist is not fighting alone. A group of people (fellowship) and the closest friends who constantly help him morally as well as physically support him everywhere.

6) Fantasy protagonist does not fight physically against the Dark Lord. His mission is to destroy the magic weapon that gives power to the evil.

From our discussion of English and Georgian fantasy protagonists, we can conclude that there are many similarities between Frodo Baggins and Lile Iroeli. Their basic functions are taken from folktale hero: the protagonist leaves home, he is given a task, he is tested, attacked, he acquires a magical weapon, he defeats and punishes the villain, and the hero is married or ascends the throne. However, both protagonists being in the fantasy story have acquired some other functions we do not meet in the folktale. The task given to both heroes is to save the world from an evil villain, who wants to rule the whole world. Consequently, fantasy protagonist fights against the global enemy. Both heroes are not as courageous as the heroes of the folktale are. They have helpers, closest friends who support them in crucial moments. They have wise mentors, who give tasks and the fellowship of other heroes, including invented creatures or speaking animals. Therefore, in the development of the new genre, fantasy protagonist has acquired other distinctive elements, which distinguish him from the folktale protagonist hero.

\section{REFERENCES}

1. Tolkien J.R.R. "The Hobbit”,Ballantine books, New York, 1986

2. Tolkien J.R.R. "The Fellowship of the Ring”,Ballantine books, New York, 1986

3. TolkienJ.R.R "The Two Towers", Ballantine books, New York, 1986

4. Tolkien J.R.R. "The Return of the King”,Ballantine books, New York, 1986

5. Dalfonzo Gina, Humble Heroism: Frodo Baggins as Christian Hero in "The Lord of the Rings", In pursuit of truth. A Journal of Christian Scholarship/28.09.2007 http://www.cslewis.org/journal/humble-heroismfrodo-baggins-as-christian-hero-in-the-lord-of-the-rings/2/

6. Propp Vladimir "Morphology of a folktale", University of Texas Press, Twentieth paperback pronting, 2009.

7. Clute John "The Encyclopedia of Fantasy", St. Martin's Griffin, New York, 1999

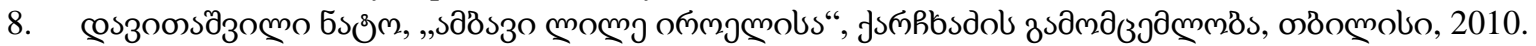

